\title{
Extracts of Euphorbia hirta Linn. (Euphorbiaceae) and Rauvolfia vomitoria Afzel (Apocynaceae) demonstrate activities against Onchocerca volvulus Microfilariae in vitro
}

\author{
Simon K Attah ${ }^{1 *}$, Patrick F Ayeh-Kumi ${ }^{1}$, Archibald A Sittie ${ }^{2}$, Isaac V Oppong ${ }^{3}$ and Alexander K Nyarko ${ }^{4}$
}

\begin{abstract}
Background: Onchocerciasis transmitted by Onchocerca volvulus is the second major cause of blindness in the world and it impacts negatively on the socio-economic development of the communities affected. Currently, ivermectin, a microfilaricidal drug is the only drug recommended for treating this disease. There have been speculations, of late, concerning $O$. volvulus resistance to ivermectin. Owing to this, it has become imperative to search for new drugs. World-wide, ethnomedicines including extracts of Euphorbia hirta and Rauvolfia vomitoria are used for treating various diseases, both infectious and non-infectious.
\end{abstract}

Method: In this study extracts of the two plants were evaluated in vitro in order to determine their effect against $O$. volvulus microfilariae. The toxicity of the E. hirta extracts on monkey kidney cell (LLCMK2) lines was also determined.

Results: The investigations showed that extracts of both plants immobilised microfilariae at different levels in vitro and, therefore, possess antifilarial properties. It was found that all the E. hirta extracts with the exception of the hexane extracts were more effective than those of $R$. vomitoria. Among the extracts of $E$. hirta the ethyl acetate fraction was most effective, and comparable to that of dimethanesulphonate salt but higher than that of Melarsoprol (Mel B). However, the crude ethanolic extract of E. hirta was found to be the least toxic to the LLCMK2 compared to the fractionated forms.

Conclusions: Extracts from both plants possess antifilarial properties; however, the crude extract of E. hirta was found to be least toxic to LLCMK2.

Keywords: Euphorbia hirta, Rauvolfia vomitoria, Onchocerca volvulus, Microfilariae, In vitro

\section{Background}

Onchocerciasis, transmitted by Onchocerca volvulus is among the major causes of blindness in the world [1-4] and has a negative impact on the socio-economic development of the communities affected [5-12]. The pathology of the disease involves mainly the microfilariae $(\mathrm{mff})$ of the parasite. Ivermectin $\left(\right.$ Mectizan $\left.^{\circledR}\right)$, the drug recommended for treatment is microfilaricidal only and has to be administered once within six to 12 months and continuously for several years [13-18]. Of late, there

\footnotetext{
* Correspondence: skwakuattah@yahoo.com

${ }^{1}$ Department of Microbiology, University of Ghana Medical School, University of Ghana, Legon, Ghana

Full list of author information is available at the end of the article
}

have been reports of emerging ivermectin resistance in the adult $O$. volvulus [19-24]. Should this be confirmed, the control of the disease will seriously be in jeopardy. In view of the limited candidate drugs available for testing against the parasite, it has become imperative to search for new drug(s) preferably a macrofilaricide(s) to treat the disease.

Presently, one area that is gaining grounds and acceptability world-wide is the evaluation and development of compounds from medicinal plants for the treatment of diseases. World-wide, ethnomedicines are used for treating various diseases, both infectious and non-infectious. In Ghana, a number of plant based products are claimed to be effective for the treatment of onchocerciasis. Among 
the medicinal plants involved Euphorbia hirta and Rauvolfia vomitoria reported to have antimicrobial properties [25-32] are used for this purpose. These have however, not been subjected to systematic evaluation to ascertain their effectiveness against $O$. volvulus. Owing to this, extracts from these two plants were selected for in vitro evaluation against the microfilariae ( $\mathrm{mff}$ ) of $O$. volvulus. The toxicity of the E. hirta extracts on monkey kidney cell (LLCMK2) lines was also determined following satisfactory results by testing its extracts.

\section{Methods}

\section{Plant collection, identification and extract preparation}

Whole plants of E. hirta and the leaves and roots of $R$. vomitoria were collected and identified at the herbarium of the Botany Department of the University of Ghana in Accra, Ghana. Voucher specimens of the plants: E. hirta (GC47751) and R. vomitoria (GC47752) were deposited at the herbarium. Whole plant specimens of E. hirta and root specimens of $R$. vomitoria were air dried for a week and pulverized into a fine powder. About $300 \mathrm{~g}$ of the pulverized E. hirta and $270 \mathrm{~g}$ of the $R$. vomitoria materials were macerated separately in three litres of $80 \%$ ethanol. After 24 hours the slurry of each plant was filtered with Whatman No.1 filter paper and concentrated under reduced pressure in a rotavapor (BUCHI Rotavapor R-114, Switzerland) at $50^{\circ} \mathrm{C}$ to recover the ethanol.

A portion of the concentrate was kept as crude extract. The remaining concentrate was partitioned with hexane $(3 \times 250 \mathrm{ml})$, chloroform $(3 \times 250 \mathrm{ml})$ and ethyl acetate $(3 \times 250 \mathrm{ml})$ sequentially (i.e. in an increasing order of polarity). Each fraction was then concentrated in vacuo at $50^{\circ} \mathrm{C}$ with the rotavapor to yield semi-solid masses. The residual (aqueous) solutions as well as the crude extracts were freeze-dried. All the extracts were stored at $-20^{\circ} \mathrm{C}$ until they were used for testing.

Dimethylsulfoxide (DMSO) was used to dissolve the plant extracts prior to diluting them into stock concentrations of $1000 \mu \mathrm{g} / \mathrm{ml}$ in MEM. Prior to testing against the mff, concentrations ranging from 6.25 to $800 \mu \mathrm{g} / \mathrm{ml}$ of each of the extracts were prepared from the working concentration such that the concentration of DMSO in each of the test solution was less than $0.1 \%$. Melarsoprol (Mel B) and dimethanesulphonate (DMSPN) salt (Ash Stevens Inc. Detriot, Michigan 48202) used as reference drugs (Strote et al., 1990a and b, 1997 and 1998) were prepared similarly.

For testing against monkey kidney cell lines (LLCMK2) 1:10 serial dilutions of the E. hirta stock solutions were prepared down to $1 \mu \mathrm{g} / \mathrm{ml}$. Potassium cyanide $(\mathrm{KCN})$ (at $1 \mathrm{mg} / \mathrm{ml}$ of MEM) solution was used as a positive control and 1\% DMSO in MEM as a solvent (or negative) control. All the solutions were sterile filtered with a $0.2 \mu \mathrm{m}$ millipore filter before testing.

\section{Selection of Subjects}

Twenty-four onchocerciasis subjects between the ages of 18 and 60 from Kpedze-Anoe and Honuta-Gbogame, who had not taken any antifilarial drugs before were admitted to the Onchocerciasis Chemotherapy Research Centre (OCRC) at Hohoe in Ghana after a written consent had been sought from each of them. The study was carried out between May 5 and August 25, 2005 following approval from the Ethical Review Board of the Noguchi Memorial Institute for Medical Research, University of Ghana.

\section{Harvesting of microfilariae}

Skin snips were taken from both iliac crests after sterilizing these sites with $70 \%$ alcohol. The snips were placed in a sterile petri-dish containing five millilitres of Eagle's Minimum Essential Medium (MEM) and left on the bench at $22^{\circ} \mathrm{C}$. After three hours of incubation, the snips were removed, medium transferred into sterile test tubes and the mff recovered by centrifugation at 1,500 rpm.

\section{Measurement of microfilaricidal action of extracts}

One millilitre of each extract and drug preparations was delivered in triplicates into a 24-well plastic plate. About $30 \mathrm{mff}$ were delivered into each well. The number of motile mff was determined at 2, 4, 6, 12, 24 and 48 hours of exposure to the extracts. The same amount of mff was exposed to concentrations between 0.01 and 1.0 per cent of DMSO (solvent control) and in plain MEM (i.e. without DMSO, drug or herbal preparation). The assays were carried out in triplicates. Microfilariae were observed under an inverted microscope and the proportion of motile/live ones determined.

\section{Inhibition determination of Euphorbia hirta extracts on monkey kidney cells}

Three hundred microlitres of MEM solution containing about 1000 monkey kidney cells were placed in each well of 96-well plates. The cells were incubated at $35^{\circ} \mathrm{C}$ in a humidified atmosphere of $5 \% \mathrm{CO}_{2}$ for a day. At the beginning of day two the culture medium was removed from the wells and replaced with $300 \mu \mathrm{l}$ of the different diluted extract to give a concentration of $0-1000 \mu \mathrm{g} / \mathrm{ml}$ and left to incubate for five days. The same volume of potassium cyanide (KCN) solution at $1 \mathrm{mg} / \mathrm{ml}$ concentration and DMSO in MEM were each delivered into three wells of the plate. The cells in three of the wells were killed with hot water and incubated with plain MEM culture medium (i.e., without any extract). In three other wells the cells were maintained with the plain culture medium. In other experiments, the cells were incubated for four days before the plant extracts were added and incubated for another two days. 
At the end of the incubation period the plant extracts were removed from the wells and replaced with $300 \mu \mathrm{l}$ of tetrazolium salt, 3-(4, 5 dimethylthiazol-2-yl)-2, 5-diphenyltetrazolium bromide (MTT) solution at $0.5 \mathrm{mg} / \mathrm{ml}$ and incubated at $35^{\circ} \mathrm{C}$. After 30 minutes the MTT solution was removed and replaced with $100 \mu \mathrm{l}$ DMSO and the plate placed in the dark at a temperature of $22^{\circ} \mathrm{C}$ for 1 hour. The formazan produced in each of the wells was transferred into corresponding wells of another microtitre plate in duplicates and the optical density (OD) determined spectrophotometrically at a wavelength of $510 \mathrm{~nm}$.

\section{Data management and statistical analysis}

Data were analyzed using Excel 2000 and Epi-info 6 programme version $6.04 \mathrm{~d}$, January 2001 . The $50 \%$ inhibition concentrations $\left(\mathrm{IC}_{50 \mathrm{~s}}\right)$ of the extracts were determined by log probit analysis, and the percentage inhibitions of the extracts on LLCMK2 were calculated using the means of the OD values. For comparison of results the chi-square test was used.

\section{Results}

\section{Effect of DMSO on microfilariae}

All the mff maintained in the various concentrations of the solvent control retained their viability up to six hours of exposure. At 12 hours of exposure, there was a slight decrease in the number of live/motile $\mathrm{mff}$ in the $0.5 \%$ concentration (i.e. a decrease of $6.4 \%$ ) and $1 \%$ concentration (i.e. a decrease of $1.8 \%$ ). The mff maintained their survival above $90 \%$ at 24 hours and between $69 \%$ and $76 \%$ at 48 hours in all the concentrations. At 48 hours of exposure about $33 \%$ of the mff were immobilised in the $1 \%$ DMSO concentration and about $22 \%$ in the plain MEM. No significant difference was found between the proportions of mff immobilised in these two solutions.

\section{Effect of the plant extracts on microfilariae}

The results from the investigations showed that motile mff were immobilised in various degrees by the $E$. hirta and $R$. vomitoria extracts in a concentration and time dependent fashion. At $2 \mathrm{hrs}$ of $\mathrm{mff}$ exposure more mff were already immobilised in the $400-800 \mu \mathrm{g} / \mathrm{ml}$ of the crude extract, $800 \mu \mathrm{g} / \mathrm{ml}$ of the hexane, $400 \mu \mathrm{g} / \mathrm{ml}$ and $800 \mu \mathrm{g} / \mathrm{ml}$ of the chloroform, $25-800 \mu \mathrm{g} / \mathrm{ml}$ of the ethyl acetate and $400 \mu \mathrm{g} / \mathrm{ml}$ and $800 \mu \mathrm{g} / \mathrm{ml}$ of the aqueous extracts of the E. hirta plant than the 1\% DMSO concentration $(\mathrm{p}<0.001)$. Immobilisation of mff continued in all the concentrations of the E. hirta extracts (with the exception of the $6.25 \mu \mathrm{g} / \mathrm{ml}$ and $12.5 \mu \mathrm{g} / \mathrm{ml}$ concentrations of the hexane extracts) and the reference drugs so much so that by $48 \mathrm{hrs}$, a significant difference was found between the proportions of mff that were immobilised in those concentrations and in the 1\% DMSO concentration
( $\mathrm{p}<0.001)$. For the $R$. vomitoria extracts more mff were found immobilised in the $400 \mu \mathrm{g} / \mathrm{ml}$ and the $800 \mu \mathrm{g} / \mathrm{ml}$ concentrations than in the $1 \%$ DMSO $(\mathrm{p}<0.001)$ from 2 hrs to 24 hrs. Similarly, with the exception of the $6.25 \mu \mathrm{g} / \mathrm{ml}$ of the crude extract and the $6.25-50 \mu \mathrm{g} / \mathrm{ml}$ of the hexane and ethyl acetate extracts, more mff were found immobilised in the lower concentrations (6.25$200 \mu \mathrm{g} / \mathrm{ml}$ ) of the extracts of this plant than in the $1 \%$ DMSO concentration at $48 \mathrm{hrs}(\mathrm{p}<0.001)$.

Table 1 shows the percentages of motile O. volvulus mff found in different concentrations of extracts of the two plants ranging between $6.25 \mu \mathrm{g} / \mathrm{ml}$ and $200 \mu \mathrm{g} / \mathrm{ml}$ at 2 and 4 hrs. The minimum concentrations of $E$. hirta found to have immobilised the mff by 2 hrs of exposure were: the $12.5 \mu \mathrm{g} / \mathrm{ml}$ concentration of the ethyl acetate, $100 \mu \mathrm{g} / \mathrm{ml}$ of the aqueous, $200 \mu \mathrm{g} / \mathrm{ml}$ of the crude, $400 \mu \mathrm{g} / \mathrm{ml}$ of the chloroform and $800 \mu \mathrm{g} / \mathrm{ml}$ of the hexane extracts. The least concentration that reduced motile mff numbers to less than 50\% among the E. hirta extracts was the $200 \mu \mathrm{g} / \mathrm{ml}$ concentration of the ethyl acetate extract. Reduction of live mff below $50 \%$ also occurred in the $400 \mu \mathrm{g} / \mathrm{ml}$ of the aqueous extract and in the crude and chloroform extracts at $800 \mu \mathrm{g} / \mathrm{ml}$ concentrations of that plant (Table 2). The various concentrations of the hexane fraction were the least active among the $E$. hirta extracts. No significant reduction of mff was seen in all the concentrations of the $R$. vomitoria extracts except in the $800 \mu \mathrm{g} / \mathrm{ml}$ chloroform and the ethyl acetate extracts (Table 2).

Among the $6.25 \mu \mathrm{g} / \mathrm{ml}$ concentrations of E. hirta immobilisation of mff occurred only in the ethyl acetate extract at 4 hours, and also occurred in the chloroform extract at 6 hrs and aqueous extracts at 12 hrs. At 4 hrs the least concentration of each of the E. hirta extract that reduced motile mff numbers to less than $50 \%$ was $50 \mu \mathrm{g} / \mathrm{ml}$ of the ethyl acetate extract, $200 \mu \mathrm{g} / \mathrm{ml}$ of the crude extract, the chloroform extract and the aqueous extract and $800 \mu \mathrm{g} / \mathrm{ml}$ of the hexane extract. At this time point, the proportion of motile mff had been reduced significantly to $2 \%$ in the $200 \mu \mathrm{g} / \mathrm{ml}$ concentration of the E. hirta ethyl acetate extract. There was no significant reduction of motile mff numbers in the concentrations of $R$. vomitoria extracts up to $200 \mu \mathrm{g} / \mathrm{ml}$ at this time point (Table 1).

Table 3 shows the percentage of motile O. volvulus mff found in concentrations of extracts of the two plants ranging between $6.25 \mu \mathrm{g} / \mathrm{ml}$ and $200 \mu \mathrm{g} / \mathrm{ml}$ at 6 and 12 hrs. At 6 hours of exposure to concentrations of the hexane extracts of $E$. hirta ranging between $6.25 \mu \mathrm{g} / \mathrm{ml}$ and $200 \mu \mathrm{g} / \mathrm{ml}$ no mff was found immobilised. Immobilisation of mff was observed in the $12.5 \mu \mathrm{g} / \mathrm{ml}$ concentrations of the remaining extracts of this plant. The reduction of motile mff numbers occurred gradually in the crude, chloroform and aqueous extracts of E. hirta 
Table 1 Percentage ( \pm SE) of motile Onchocerca volvulus microfilariae found in $6.25 \mu \mathrm{g} / \mathrm{ml}$ to $200 \mu \mathrm{g} / \mathrm{ml} \mathrm{of} \mathrm{Euphorbia}$ hirta and Rauvolfia vomitoria extracts at 2 and 4 hrs

\begin{tabular}{|c|c|c|c|c|c|c|c|c|c|c|c|c|}
\hline \multirow{3}{*}{$\begin{array}{l}\text { Extract/ } \\
\text { drug }\end{array}$} & \multicolumn{12}{|c|}{ Extract concentration $(\mu \mathrm{g} / \mathrm{ml})$} \\
\hline & \multicolumn{2}{|c|}{$6.25(\mu \mathrm{g} / \mathrm{ml})$} & \multicolumn{2}{|c|}{$12.5(\mu \mathrm{g} / \mathrm{ml})$} & \multicolumn{2}{|c|}{$25(\mu \mathrm{g} / \mathrm{ml})$} & \multicolumn{2}{|c|}{$50(\mu \mathrm{g} / \mathrm{ml})$} & \multicolumn{2}{|c|}{$100(\mu \mathrm{g} / \mathrm{ml})$} & \multicolumn{2}{|c|}{$200(\mu \mathrm{g} / \mathrm{ml})$} \\
\hline & $2 \mathrm{hrs}$ & $4 \mathrm{hrs}$ & $2 \mathrm{hrs}$ & $4 \mathrm{hrs}$ & $2 \mathrm{hrs}$ & $4 \mathrm{hrs}$ & $2 \mathrm{hrs}$ & 4 hrs & $2 \mathrm{hrs}$ & $4 \mathrm{hrs}$ & $2 \mathrm{hrs}$ & $4 \mathrm{hrs}$ \\
\hline \multicolumn{13}{|c|}{ Euphorbia hirta } \\
\hline Crude & 100 & 100 & 100 & $97( \pm 3)$ & 100 & $95( \pm 5)$ & 100 & $90( \pm 10)$ & 100 & $55( \pm 29)$ & $73( \pm 24)$ & $36( \pm 32)$ \\
\hline Hexane & 100 & 100 & 100 & 100 & 100 & 100 & 100 & 100 & 100 & 100 & 100 & 100 \\
\hline Chloroform & 100 & 100 & 100 & $97( \pm 3)$ & 100 & $92( \pm 8)$ & 100 & $69( \pm 22)$ & 100 & $71( \pm 22)$ & 100 & $32( \pm 21)$ \\
\hline Ethyl acetate & 100 & $98( \pm 2)$ & $98( \pm 2)$ & $96( \pm 2)$ & $64( \pm 28)$ & $54( \pm 27)$ & $55( \pm 29)$ & $46( \pm 23)$ & $54( \pm 29)$ & $38( \pm 28)$ & $35( \pm 19)$ & $2( \pm 2)$ \\
\hline Aqueous & 100 & 100 & 100 & 100 & 100 & 100 & 100 & 100 & $96( \pm 4)$ & $62( \pm 25)$ & $94( \pm 4)$ & $43( \pm 28)$ \\
\hline \multicolumn{13}{|c|}{ Rauvolfia vomitoria } \\
\hline Crude & 100 & 100 & 100 & 100 & 100 & 100 & 100 & 100 & 100 & 100 & 100 & $90( \pm 10)$ \\
\hline Hexane & 100 & 100 & 100 & 100 & 100 & 100 & 100 & 100 & 100 & 100 & 100 & 100 \\
\hline Chloroform & 100 & 100 & 100 & 100 & 100 & 100 & 100 & 100 & 100 & 100 & 100 & $98( \pm 2)$ \\
\hline Ethyl acetate & 100 & 100 & 100 & 100 & 100 & 100 & 100 & 100 & 100 & 100 & 100 & 100 \\
\hline Aqueous & 100 & 100 & 100 & 100 & 100 & 100 & 100 & 100 & 100 & 100 & 100 & 100 \\
\hline \multicolumn{13}{|c|}{ Reference drugs } \\
\hline DMSPN & 100 & 100 & 100 & $92( \pm 8)$ & $97( \pm 3)$ & $70( \pm 20)$ & $67( \pm 33)$ & $38( \pm 27)$ & $49( \pm 28)$ & $17( \pm 12)$ & $44( \pm 28)$ & $14( \pm 8)$ \\
\hline Mel B & 100 & 100 & 100 & 100 & 100 & $99( \pm 1)$ & 100 & $99( \pm 1)$ & 100 & $99( \pm 1)$ & $94( \pm 6)$ & $81( \pm 11)$ \\
\hline
\end{tabular}

but the rate of reduction was faster in the ethyl acetate extract of this plant. The minimum concentration that immobilised more than $90 \%$ of the mff at this time point was the $100 \mu \mathrm{g} / \mathrm{ml}$ of the ethyl acetate, $400 \mu \mathrm{g} / \mathrm{ml}$ of the chloroform, aqueous and crude extracts and $800 \mu \mathrm{g} / \mathrm{ml}$ of the hexane extract (Table 2). No significant difference was found between the effect of the aqueous extract and that of the chloroform or the crude extracts. A significant difference was however found between the effectiveness of the aqueous extract and that of the hexane

Table 2 Percentage ( \pm SE) of motile Onchocerca volvulus microfilariae found in $400 \mu \mathrm{g} / \mathrm{ml}$ and $800 \mu \mathrm{g} / \mathrm{ml} \mathrm{of} \mathrm{Euphorbia}$ hirta and Rauvolfia vomitoria extracts at 2 to 48 hrs

\begin{tabular}{|c|c|c|c|c|c|c|c|c|c|c|c|c|}
\hline \multirow{3}{*}{$\begin{array}{l}\text { Extract/ } \\
\text { drug }\end{array}$} & \multicolumn{12}{|c|}{ Extract concentration $(\mu \mathrm{g} / \mathrm{ml})$} \\
\hline & 400 & 800 & 400 & 800 & 400 & 800 & 400 & 800 & 400 & 800 & 400 & 800 \\
\hline & \multicolumn{2}{|l|}{$2 \mathrm{hrs}$} & \multicolumn{2}{|l|}{$4 \mathrm{hrs}$} & \multicolumn{2}{|l|}{$6 \mathrm{hrs}$} & \multicolumn{2}{|l|}{$12 \mathrm{hrs}$} & \multicolumn{2}{|l|}{$24 \mathrm{hrs}$} & \multicolumn{2}{|l|}{$48 \mathrm{hrs}$} \\
\hline \multicolumn{13}{|c|}{ Euphorbia hirta } \\
\hline Crude & $55( \pm 24)$ & $27( \pm 23)$ & $31( \pm 26)$ & $12( \pm 12)$ & $2( \pm 2)$ & 0 & 0 & 0 & 0 & 0 & 0 & 0 \\
\hline Hexane & 100 & $64( \pm 32)$ & $87( \pm 13)$ & $33( \pm 33)$ & $87( \pm 13)$ & 0 & $43( \pm 20)$ & 0 & $4( \pm 4)$ & 0 & 0 & 0 \\
\hline Chloroform & $50( \pm 17)$ & $12( \pm 9)$ & $17( \pm 17)$ & $10( \pm 1)$ & 0 & 0 & 0 & 0 & 0 & 0 & 0 & 0 \\
\hline Ethyl acetate & $24( \pm 24)$ & $10( \pm 10)$ & $2( \pm 2)$ & $2( \pm 2)$ & 0 & 0 & 0 & 0 & 0 & 0 & 0 & 0 \\
\hline Aqueous & $46( \pm 27)$ & $32( \pm 21)$ & $28( \pm 18)$ & $24( \pm 24)$ & $2( \pm 2)$ & 0 & 0 & 0 & 0 & 0 & 0 & 0 \\
\hline \multicolumn{13}{|c|}{ Rauvolfia vomitoria } \\
\hline Crude & $88( \pm 12)$ & $88( \pm 12)$ & $48( \pm 22)$ & $33( \pm 27)$ & $42( \pm 27)$ & $33( \pm 33)$ & $30( \pm 30)$ & 0 & $30( \pm 30)$ & 0 & $22( \pm 22)$ & 0 \\
\hline Hexane & $98( \pm 2)$ & $87( \pm 13)$ & $96( \pm 2)$ & $33( \pm 33)$ & $96( \pm 2)$ & 0 & $70( \pm 18)$ & 0 & $21( \pm 5)$ & 0 & $8( \pm 8)$ & 0 \\
\hline Chloroform & $80( \pm 15)$ & $30( \pm 10)$ & $76( \pm 13)$ & $17( \pm 17)$ & $59( \pm 30)$ & $6( \pm 6)$ & $56( \pm 28)$ & 0 & $53( \pm 27)$ & 0 & 0 & 0 \\
\hline Ethyl acetate & 100 & $12( \pm 12)$ & $97( \pm 3)$ & 0 & $97( \pm 3)$ & 0 & $94( \pm 3)$ & 0 & $60( \pm 30)$ & 0 & $7( \pm 7)$ & 0 \\
\hline Aqueous & 100 & 100 & $88( \pm 9)$ & $67( \pm 33)$ & $88( \pm 9)$ & $42( \pm 30)$ & $65( \pm 32)$ & $23( \pm 23)$ & $59( \pm 30)$ & $23( \pm 23)$ & $30( \pm 30)$ & 0 \\
\hline \multicolumn{13}{|c|}{ Reference drugs } \\
\hline DMSPN & $44( \pm 28)$ & $15( \pm 15)$ & $11( \pm 9)$ & 0 & 0 & 0 & 0 & 0 & 0 & 0 & 0 & 0 \\
\hline Mel B & $88( \pm 5)$ & $3( \pm 3)$ & $65( \pm 11)$ & 0 & $55( \pm 2)$ & 0 & 0 & 0 & 0 & 0 & 0 & 0 \\
\hline
\end{tabular}

NB: in $1 \%$ DMSO $99 \%, 93.1 \%$ and $68 \%$ of mff were motile at $12 \mathrm{hrs}, 24$ and 48 hrs of exposure respectively. 
Table 3 Percentage ( \pm SE) of motile Onchocerca volvulus microfilariae found in $6.25 \mu \mathrm{g} / \mathrm{ml}$ to $200 \mu \mathrm{g} / \mathrm{ml} \mathrm{of} \mathrm{Euphorbia}$ hirta and Rauvolfia vomitoria extracts at 6 and 12 hrs

\begin{tabular}{|c|c|c|c|c|c|c|c|c|c|c|c|c|}
\hline \multirow{3}{*}{$\begin{array}{l}\text { Extract/ } \\
\text { drug }\end{array}$} & \multicolumn{12}{|c|}{ Extract concentration $(\mu \mathrm{g} / \mathrm{ml})$} \\
\hline & \multicolumn{2}{|c|}{$6.25(\mu \mathrm{g} / \mathrm{ml})$} & \multicolumn{2}{|c|}{$12.5(\mu \mathrm{g} / \mathrm{ml})$} & \multicolumn{2}{|c|}{$25(\mu \mathrm{g} / \mathrm{ml})$} & \multicolumn{2}{|c|}{$50(\mu \mathrm{g} / \mathrm{ml})$} & \multicolumn{2}{|c|}{$100(\mu \mathrm{g} / \mathrm{ml})$} & \multicolumn{2}{|c|}{$200(\mu \mathrm{g} / \mathrm{ml})$} \\
\hline & $6 \mathrm{hrs}$ & $12 \mathrm{hrs}$ & $6 \mathrm{hrs}$ & $12 \mathrm{hrs}$ & $6 \mathrm{hrs}$ & $12 \mathrm{hrs}$ & $6 \mathrm{hrs}$ & $12 \mathrm{hrs}$ & $6 \mathrm{hrs}$ & $12 \mathrm{hrs}$ & $6 \mathrm{hrs}$ & $12 \mathrm{hrs}$ \\
\hline \multicolumn{13}{|c|}{ Euphorbia hirta } \\
\hline Crude & 100 & 100 & $95( \pm 5)$ & $93( \pm 4)$ & $95( \pm 5)$ & $93( \pm 4)$ & $83( \pm 9)$ & $50( \pm 25)$ & $15( \pm 13)$ & $4( \pm 4)$ & $13( \pm 10)$ & $4( \pm 4)$ \\
\hline Hexane & 100 & 100 & 100 & 100 & 100 & 100 & 100 & 100 & 100 & $85( \pm 1)$ & 100 & $63( \pm 18)$ \\
\hline Chloroform & 100 & $94( \pm 6)$ & $94( \pm 6)$ & $94( \pm 6)$ & $92( \pm 8)$ & $82( \pm 11)$ & $67( \pm 26)$ & $42( \pm 23)$ & $67( \pm 26)$ & $14( \pm 14)$ & $22( \pm 12)$ & $10( \pm 5)$ \\
\hline Ethyl acetate & $96( \pm 4)$ & $77( \pm 6)$ & $85( \pm 8)$ & $77( \pm 6)$ & $39( \pm 24)$ & $10( \pm 6)$ & $20( \pm 10)$ & 0 & $2( \pm 2)$ & 0 & $2( \pm 2)$ & 0 \\
\hline Aqueous & 100 & $83( \pm 10)$ & $97( \pm 3)$ & $82( \pm 10)$ & $85( \pm 11)$ & $50( \pm 26)$ & $73( \pm 18)$ & $50( \pm 26)$ & $47( \pm 27)$ & $18( \pm 10)$ & $29( \pm 29)$ & $8( \pm 8)$ \\
\hline \multicolumn{13}{|c|}{ Rauvolfia vomitoria } \\
\hline Crude & 100 & 100 & 100 & 100 & 100 & 100 & 100 & $93( \pm 7)$ & $96( \pm 4)$ & $83( \pm 17)$ & $76( \pm 24)$ & $67( \pm 33)$ \\
\hline Hexane & 100 & 100 & 100 & 100 & 100 & 100 & 100 & 100 & 100 & 100 & 100 & $95( \pm 5)$ \\
\hline Chloroform & 100 & 100 & 100 & $98( \pm 2)$ & 100 & $98( \pm 2)$ & 100 & $97( \pm 3)$ & 100 & $97( \pm 3)$ & $98( \pm 2)$ & $65( \pm 33)$ \\
\hline Ethyl acetate & 100 & 100 & 100 & 100 & 100 & 100 & 100 & 100 & 100 & 100 & 100 & 100 \\
\hline Aqueous & 100 & $96( \pm 4)$ & 100 & 100 & 100 & 100 & 100 & 100 & 100 & 100 & 100 & $91( \pm 6)$ \\
\hline \multicolumn{13}{|c|}{ Reference drugs } \\
\hline DMSPN & 100 & $84( \pm 16)$ & $64( \pm 18)$ & $55( \pm 23)$ & $38( \pm 26)$ & $19( \pm 16)$ & $33( \pm 24)$ & $10( \pm 10)$ & $11( \pm 9)$ & $10( \pm 10)$ & $5( \pm 5)$ & $5( \pm 5)$ \\
\hline Mel B & $94( \pm 6)$ & $87( \pm 8)$ & $94( \pm 6)$ & $87( \pm 10)$ & $94( \pm 6)$ & $87( \pm 8)$ & $94( \pm 6)$ & $64( \pm 14)$ & $94( \pm 6)$ & $43( \pm 23)$ & $71( \pm 21)$ & $10( \pm 5)$ \\
\hline
\end{tabular}

extract $(\mathrm{P}<0.001)$. In the case of the $R$. vomitoria extracts, no significant reduction of live mff numbers was observed except in the $400 \mu \mathrm{g} / \mathrm{ml}$ concentration of the crude extract and the $800 \mu \mathrm{g} / \mathrm{ml}$ concentration of the other extracts up to this time point of mff exposure (Table 2).
In the $6.25 \mu \mathrm{g} / \mathrm{ml}$ concentration of the E. hirta extracts all the mff were motile in the crude and hexane extracts up to 12 hours of their exposure. At this time point, no live mff were found in concentrations higher than $25 \mu \mathrm{g} / \mathrm{ml}$ of the ethyl acetate extract. Live mff numbers fell below $20 \%$ in the $100 \mu \mathrm{g} / \mathrm{ml}$ and $200 \mu \mathrm{g} / \mathrm{ml}$

Table 4 Percentage ( \pm SE) of motile Onchocerca volvulus microfilariae found in $6.25 \mu \mathrm{g} / \mathrm{ml}$ to $200 \mu \mathrm{g} / \mathrm{ml} \mathrm{of} \mathrm{Euphorbia}$ hirta and Rauvolfia vomitoria extracts at 24 and 48 hrs

\begin{tabular}{|c|c|c|c|c|c|c|c|c|c|c|c|c|}
\hline \multirow{3}{*}{$\begin{array}{l}\text { Extract/ } \\
\text { drug }\end{array}$} & \multicolumn{12}{|c|}{ Extract concentration $(\mu \mathrm{g} / \mathrm{ml})$} \\
\hline & \multicolumn{2}{|c|}{$6.25(\mu \mathrm{g} / \mathrm{ml})$} & \multicolumn{2}{|c|}{$12.5(\mu \mathrm{g} / \mathrm{ml})$} & \multicolumn{2}{|c|}{$25(\mu \mathrm{g} / \mathrm{ml})$} & \multicolumn{2}{|c|}{$50(\mu \mathrm{g} / \mathrm{ml})$} & \multicolumn{2}{|c|}{$100(\mu \mathrm{g} / \mathrm{ml})$} & \multicolumn{2}{|c|}{$200(\mu \mathrm{g} / \mathrm{ml})$} \\
\hline & $24 \mathrm{hrs}$ & 48 hrs & 24 hrs & 48 hrs & $24 \pm$ hrs & $48 \mathrm{hrs}$ & 24 hrs & 48 hrs & $24 \mathrm{hrs}$ & $48 \mathrm{hrs}$ & 24 hrs & $48 \mathrm{hrs}$ \\
\hline \multicolumn{13}{|c|}{ Euphorbia hirta } \\
\hline Crude & $73( \pm 19)$ & $34( \pm 25)$ & $67( \pm 21)$ & $34( \pm 25)$ & $67( \pm 21)$ & $25( \pm 25)$ & $35( \pm 22)$ & 0 & $4( \pm 4)$ & 0 & $4( \pm 4)$ & 0 \\
\hline Hexane & $96( \pm 4)$ & $62( \pm 20)$ & $96( \pm 4)$ & $54( \pm 23)$ & $78( \pm 13)$ & $44( \pm 1)$ & $74( \pm 1)$ & $44( \pm 1)$ & $74( \pm 1)$ & $33( \pm 1)$ & $38( \pm 31)$ & $12( \pm 12)$ \\
\hline Chloroform & $77( \pm 12)$ & $33( \pm 33)$ & $63( \pm 23)$ & $33( \pm 33)$ & $63( \pm 22)$ & $25( \pm 25)$ & $20( \pm 20)$ & 0 & 0 & 0 & 0 & 0 \\
\hline Ethyl acetate & $27( \pm 27)$ & 0 & $27( \pm 27)$ & 0 & 0 & 0 & 0 & 0 & 0 & 0 & 0 & 0 \\
\hline Aqueous & $65( \pm 19)$ & $33( \pm 33)$ & $62( \pm 19)$ & $33( \pm 33)$ & $39( \pm 19)$ & 0 & $23( \pm 17)$ & 0 & $10( \pm 5)$ & 0 & $8( \pm 8)$ & 0 \\
\hline \multicolumn{13}{|c|}{ Rauvolfia vomitoria } \\
\hline Crude & $92( \pm 1)$ & $33( \pm 33)$ & $92( \pm 1)$ & $33( \pm 33)$ & $92( \pm 1)$ & $33( \pm 33)$ & $87( \pm 13)$ & $33( \pm 33)$ & $71( \pm 29)$ & $33( \pm 33)$ & $67( \pm 33)$ & $33( \pm 33)$ \\
\hline Hexane & $89( \pm 11)$ & $33( \pm 33)$ & $89( \pm 11)$ & $33( \pm 33)$ & $80( \pm 1)$ & $33( \pm 33)$ & $72( \pm 20)$ & $33( \pm 33)$ & $71( \pm 20)$ & $33( \pm 33)$ & $46( \pm 27)$ & $33( \pm 33)$ \\
\hline Chloroform & 100 & $33( \pm 33)$ & $97( \pm 3)$ & $33( \pm 33)$ & $97( \pm 3)$ & $33( \pm 33)$ & $97( \pm 3)$ & $33( \pm 33)$ & $97( \pm 3)$ & $33( \pm 33)$ & $64( \pm 22)$ & 0 \\
\hline Ethyl acetate & 100 & $67( \pm 33)$ & 100 & $67( \pm 33)$ & 100 & $63( \pm 32)$ & 100 & $33( \pm 33)$ & $67( \pm 33)$ & $33( \pm 33)$ & $67( \pm 33)$ & $33( \pm 33)$ \\
\hline Aqueous & 100 & $33( \pm 33)$ & 100 & $33( \pm 33)$ & 100 & $33( \pm 33)$ & $79( \pm 18)$ & $33( \pm 33)$ & $78( \pm 22)$ & $33( \pm 33)$ & $59( \pm 30)$ & $30( \pm 30)$ \\
\hline \multicolumn{13}{|c|}{ Reference drugs } \\
\hline DMSPN & $49( \pm 26)$ & $17( \pm 17)$ & $25( \pm 25)$ & $8( \pm 8)$ & $3( \pm 3)$ & 0 & $3( \pm 3)$ & 0 & $3( \pm 3)$ & 0 & $2( \pm 2)$ & 0 \\
\hline Mel B & $22( \pm 22)$ & $17( \pm 17)$ & $22(22)$ & 0 & $6( \pm 6)$ & 0 & $6( \pm 6)$ & 0 & 0 & 0 & 0 & 0 \\
\hline
\end{tabular}


concentrations, and fell to zero in the $400 \mu \mathrm{g} / \mathrm{ml}$ and $800 \mu \mathrm{g} / \mathrm{ml}$ concentrations of the crude, chloroform and aqueous extracts. In the $R$. vomitoria extracts all the mff were motile up to 12 hours when they were exposed to the $6.25 \mu \mathrm{g} / \mathrm{ml}$ concentration. No $\mathrm{mff}$ was found immobilised in the hexane extracts of $E$. hirta at concentrations lower than $400 \mu \mathrm{g} / \mathrm{ml}$ except in the $100 \mu \mathrm{g} / \mathrm{ml}$ and $200 \mu \mathrm{g} / \mathrm{ml}$ concentrations.

Table 4 shows the percentage of motile mff exposed to the $6.25 \mu \mathrm{g} / \mathrm{ml}$ to $200 \mu \mathrm{g} / \mathrm{ml}$ concentrations of $E$. hirta and $R$. vomitoria extracts at $24 \mathrm{hrs}$ and $48 \mathrm{hrs}$ and Table 2 shows the percentage of motile mff exposed to the $400 \mu \mathrm{g} / \mathrm{ml}$ and $800 \mu \mathrm{g} / \mathrm{ml}$ concentrations of E. hirta and $R$. vomitoria extracts at $2-24 \mathrm{hrs}$. At $24 \mathrm{hrs}$ of exposure to the $E$. hirta extracts the proportion of motile mff were found to have been reduced drastically. The lowest concentration that killed all the $\mathrm{mff}$ at this time point in the case of the ethyl acetate extract was $25 \mu \mathrm{g} / \mathrm{ml}$; chloroform extract, $100 \mu \mathrm{g} / \mathrm{ml}$ (Table 4) and aqueous extract, $400 \mu \mathrm{g} / \mathrm{ml}$; hexane extract, $800 \mu \mathrm{g} / \mathrm{ml}$ and the crude extract, $400 \mu \mathrm{g} / \mathrm{ml}$ (Table 2). In all the plant extract concentrations, only in the $800 \mu \mathrm{g} / \mathrm{ml}$ concentration of the aqueous extract of $R$. vomitoria were motile $\mathrm{mff}$ seen at the same time point (Table 2). By $48 \mathrm{hrs,}$, all the mff were immobilised in all the concentrations of the ethyl acetate extract of $E$. hirta and in the $800 \mu \mathrm{g} / \mathrm{ml}$ concentrations of both the E. hirta and $R$. vomitoria extracts (Tables 2 and 4). At this time point, with the E. hirta plant, motile mff were found in the $6.25 \mu \mathrm{g} / \mathrm{ml}$ and $12.5 \mu \mathrm{g} / \mathrm{ml}$ concentrations of the aqueous extract and the $6.25 \mu \mathrm{g} / \mathrm{ml}$ to $25 \mu \mathrm{g} / \mathrm{ml}$ concentrations of the chloroform and crude extracts and $6.25-200 \mu \mathrm{g} / \mathrm{ml}$ of the hexane extract.

Generally, the extracts of $E$. hirta were more effective in immobilising the $\mathrm{mff}$ and their $\mathrm{IC}_{50 \mathrm{~s}}$ were lower than those of $R$. vomitoria. At 2-24 hrs the extracts of $E$. hirta were found to be more effective in immobilising mff than those of $R$. vomitoria and the difference was significant $(\mathrm{P}<0.004)$. There was no significant difference between the ethyl acetate extract of E. hirta and DMSPN at any time point with regards to their effectiveness. The various concentrations of Mel B were less effective in immobilising motile mff than those of the ethyl acetate extract of $E$. hirta $(\mathrm{P}<0.019)$ and those of DMSPN $(\mathrm{P}<0.01)$ at $2-6 \mathrm{hrs}$ (Tables 1 and 3). Table 5 shows the 50\% inhibition concentrations $\left(\mathrm{IC}_{50 \mathrm{~s}}\right)$ of the plant extracts and the reference drugs on $O$. volvulus mff. The $\mathrm{IC}_{50 \text { s }}$ of all the extracts and the reference drugs decreased consistently over time. The $E$. hirta extracts with the exception of that of the hexane had lower $\mathrm{IC}_{50 \mathrm{~s}}$ than those of $R$. vomitoria at $24 \mathrm{hrs}$ and Mel B at $12 \mathrm{hrs}$. Among the E. hirta extracts that of ethyl acetate had the least
Table 5 Fifty per cent inhibition concentrations $\left(\right.$ IC $\left._{50 s}\right)$ of Euphorbia hirta and Rauvolfia vomitoria extracts on Onchocerca volvulus microfilariae

\begin{tabular}{|c|c|c|c|c|c|c|}
\hline \multirow[t]{2}{*}{ Extract/Drug } & \multicolumn{6}{|c|}{ Time of mff exposure (hrs) } \\
\hline & 2 & 4 & 6 & 12 & 24 & 48 \\
\hline \multicolumn{7}{|c|}{$\mathrm{IC}_{50 \mathrm{~s}}$ of Euphorbia hirta $(\mu \mathrm{g} / \mathrm{ml})$} \\
\hline Crude & 500 & 125 & 75 & 50 & 40 & $<6.25$ \\
\hline Hexane & $>800$ & 700 & 700 & 700 & 150 & 17.5 \\
\hline Chloroform & 400 & 150 & 140 & 50 & 20 & $<6.25$ \\
\hline Ethyl acetate & 100 & 37.5 & 21.9 & 12.5 & $<6.25$ & $<6.25$ \\
\hline Water & 400 & 150 & 90 & 25 & 18.8 & $<6.25$ \\
\hline \multicolumn{7}{|c|}{$\mathrm{IC}_{50 \mathrm{~s}}$ of Rauvolfia vomitoria $(\mu \mathrm{g} / \mathrm{ml})$} \\
\hline Crude & $>800$ & 400 & 350 & 300 & 300 & $<6.25$ \\
\hline Hexane & $>800$ & 700 & 600 & 450 & 200 & $<6.25$ \\
\hline Chloroform & 650 & 600 & 450 & 400 & 400 & $<6.25$ \\
\hline Ethyl acetate & 650 & 625 & 625 & 625 & 450 & 37.5 \\
\hline Water & $>800$ & $>800$ & 800 & 400 & 200 & $<6.25$ \\
\hline \multicolumn{7}{|c|}{$\mathrm{IC}_{50 \mathrm{~s}}$ of the reference drugs $(\mu \mathrm{g} / \mathrm{ml})$} \\
\hline DMSPN & 100 & 40.5 & 18.8 & 14.1 & 6.25 & $<6.25$ \\
\hline Mel B & 600 & 500 & 400 & 87.5 & $<6.25$ & $<6.25$ \\
\hline
\end{tabular}

$\mathrm{IC}_{50 \mathrm{~s}}$ which were comparable to those of DMSPN up to $24 \mathrm{hrs}$. With the exception of the hexane extract of $E$. hirta and the ethyl acetate extract of $R$. vomitoria, the $\mathrm{IC}_{50 \mathrm{~s}}$ of all the extracts as well as DMSPN and Mel B fell below $6.25 \mu \mathrm{g} / \mathrm{ml}$ at $48 \mathrm{hrs}$. From the foregoing, it can be deduced that the E. hirta ethyl acetate extract (which had the least $\mathrm{IC}_{50 \mathrm{~s}}$ ) was the most effective.

\section{Effect of $E$. hirta extracts on monkey kidney cell lines}

Figure 1 shows the effect of $E$. hirta extracts on the viability of monkey kidney cells maintained for one day prior to the exposure of the extracts for five days. In this figure the crude extracts were seen to exhibit negative inhibition on the LLCMK2. All the extracts with the exception of that of chloroform at $1000 \mu \mathrm{g} / \mathrm{ml}$ concentration also inhibited the cells negatively (i.e. promoted cell proliferation) when they were maintained in culture for four days before being exposed to the extracts for two days (Figure 2).

Among these extracts only the crude extract inhibited the cells in a concentration dependent fashion with the lowest concentration having the highest effect and vice versa. At each concentration the crude extract exhibited the lowest inhibition on the cells. The $1000 \mu \mathrm{g} / \mathrm{ml}$ concentration of the hexane extract showed the highest inhibition and the $100 \mu \mathrm{g} / \mathrm{ml}$ the lowest in these two experiments. In the first experiment the highest inhibition on the cells was exhibited 


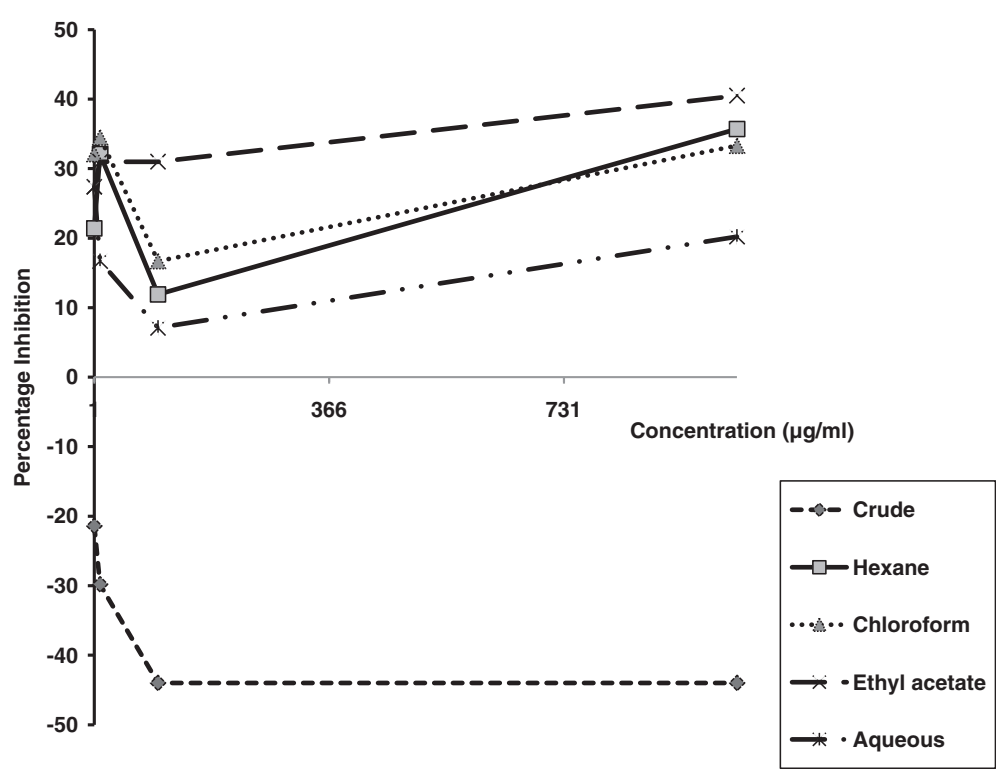

Figure 1 Percentage inhibition of monkey kidney cells lines maintained in culture for one day before exposure to Euphorbia hirta extracts for $\mathbf{5}$ days ${ }^{1}$. 1. Percentage inhibition of potassium cyanide $(\mathrm{KCN})$ at $10^{3} \mu \mathrm{g} / \mathrm{ml}=131 \%$; the optical density (OD) values for: $1 \%$ DMSO (solvent control) $=0.069$, cells cultured in plain culture medium $=0.093$, and for heat killed cells $=-0.015$ (negative figures imply promotion of cell maintenance).

by the $10 \mu \mathrm{g} / \mathrm{ml}$, the $1000 \mu \mathrm{g} / \mathrm{ml}$ and the $1 \mu \mathrm{g} / \mathrm{ml}$ concentrations of the chloroform, ethyl acetate and water respectively whilst the $100 \mu \mathrm{g} / \mathrm{ml}, 1 \mu \mathrm{g} / \mathrm{ml}$, and $100 \mu \mathrm{g} / \mathrm{ml}$ concentrations in the same order had the lowest effect on the cells (Figure 1). In the second experiment the $1000 \mu \mathrm{g} / \mathrm{ml}$ concentration of the chloroform and ethyl acetate extract as well as the $1 \mu \mathrm{g} / \mathrm{ml}$ concentration of the aqueous extract had the highest whilst the $100 \mu \mathrm{g} / \mathrm{ml}$ concentrations of the chloroform, ethyl acetate and aqueous extracts respectively had the lowest

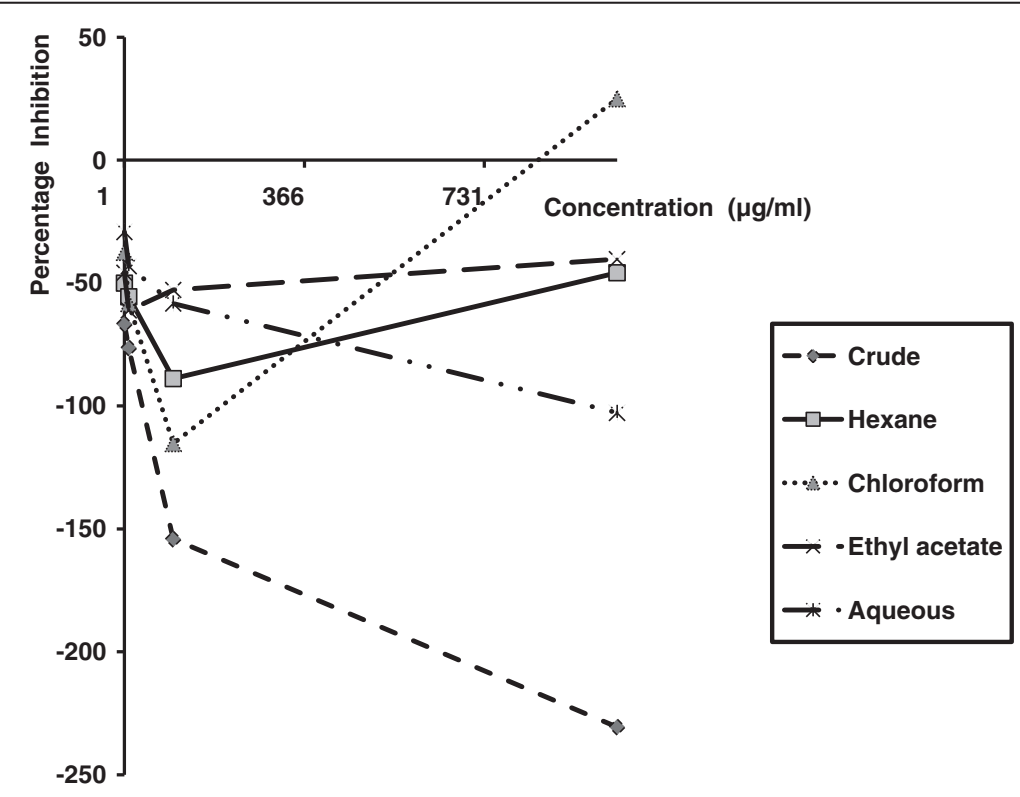

Figure 2 Percentage inhibition of monkey kidney cells lines maintained in culture for four days before exposure to Euphorbia hirta extracts for two days ${ }^{2}$. 2. Percentage inhibition of potassium cyanide (KCN) at $10^{3} \mu \mathrm{g} / \mathrm{ml}=52.8 \%$; the optical density (OD) values for $1 \%$ DMSO (solvent control) $=0.109$, cells cultured in plain culture medium $=0.149$, and for heat killed cells $=-0.037$ (negative figures imply promotion of cell maintenance). 
inhibitory effect on the cells (Figure 2).

\section{Discussion}

To date, not much work has been done to investigate the efficacy of plant extracts against human filarial parasites except those conducted by Kilian et al. (1990) using Cassia aubrevillei [33] and Titanji et al. (1990) using Polyalthia suaveolens [34]. Most of the work conducted so far involved the use of animal filarial parasites. Some of the plants used were Acacia auriculiformis [35], Sancio nudicaulis Buch. Ham. [36], Saxifraga stracheyion root [37], Centratherum anthelminticum seeds [38], Azadirachta indica and Ficus racemosa Linn. [39,40]. Comley et al. (1990) reported the macrofilaricidal effects in vitro of filaricid (a crude extract of the stem bark of Streblus asper, Lour) and filarin (a crude extract comprising five plants in different proportions) against Acanthocheilonema viteae females at $500 \mu \mathrm{g} / \mathrm{ml}$ [41]. They also found that oliverine derived from $\mathrm{n}$-hexane extract of the stem bark of Pachypodanthium staudtii has similar effects on the Acanthocheilonema viteae worm at 120 hours down to $10 \mu \mathrm{g} / \mathrm{ml}$.

In spite of reports concerning $E$. hirta and $R$. vomitoria possessing antimicrobial properties, no systematic studies on their effectiveness against filarial parasites either in vivo or in vitro have been carried out. The results of this study has indicated that extracts of these two plants possess antifilarial properties. Among the E. hirta extracts, that of ethyl acetate was most effective, and this was comparable to that of DMSPN but more effective than Mel B. The hexane extract of E. hirta and the extracts of $R$. vomitoria showed least activity before 48 hours of mff exposure. A lot of chemical constituents including diterpenes, flavonoids, tannins, aromatic acids, alkaloids, coumarins and anthocyanins, euphorbon, triterpenes and quercetol have been isolated from every part of $E$. hirta $[28,29]$. The root of $R$. vomitoria, on the other hand, contains flavonoids and over 100 alkaloids including reserpine, rescinnamine, deserpidine, yohimbine, aijmaline and alstonine which are therapeutically important [27-29].

Notwithstanding the efficacy of $E$. hirta extracts against these diseases, issues have been raised concerning the toxicity of the extracts. For instance, Adedapo et al. (2005) in conducting in vivo work showed that some chromatographic fractions of the plant have potentially deleterious effect on the serum chemistry of rats. They therefore cautioned against the use of this plant for medicinal purposes. Contrary to these findings, Hashemi et al. (2008) observed a significant decrease in Aspartate transaminase (AST), Alanine aminotransferase (ALT), and Alkaline phosphatase (ALP) after 14 days of oral administration of $2000 \mathrm{mg} / \mathrm{kg}$ of the crude aqueous extracts of E. hirta to chicks [42]. Ogueke et al. (2007) found the crude ethanolic extracts of the plant at concentrations ranging from 60.4 to $483.0 \mathrm{mg} / \mathrm{kg}$ body weight to be haematologically safe to albino rats. Biochemical analyses of the renal and hepato-biliary function following oral administration of up to $3000 \mathrm{mg} / \mathrm{kg}$ body weight of the crude extracts of the plant were also found to be haematologically safe and did not show any signs of nephrotoxicity and hepatotoxicity in rats, as confirmed by histopathological examination [43].

E. hirta has been used to treat various diseases by traditional herbal practitioners and its administration has mainly been through the oral route [25,28-30]. In this study, the crude extract of E. hirta inhibited cell growth the least. Moreover, it was the only extract that was found to have exhibited its effect in a concentration dependent fashion with the highest concentration having the least inhibitory effect. This observation is in agreement with that of Brindha et al. (2010) who observed a dose-dependent increase in viability when antitubercular drug exposed human liver derived HepG2 cells were treated with different concentrations of extracts of the plant [44].

In the current study, when the cells were maintained for a longer period before being exposed to the extracts, the survival of the cells was enhanced more than when they were maintained for a shorter period before their exposure to the extracts. This observation was most pronounced when the cells were exposed to the crude extracts. This observation can be explained by the fact that once the cells form confluence they are inhibited less than when they have not. A previous investigation by Raja Sidambaram et al. (2011) using the methanol extract of the leaves of E. hirta on Hep--2 cells from human epithelioma of the larynx showed a dose dependent antitumor activity in vitro [45]. The extracts in the current investigation have also revealed antiproliferative effects on the cells that have not achieved complete attachment to the plates. This finding shows that extracts from the plant have the potential to serve as anticancer agents. The promotion of the vitality of the monkey kidney cells particularly by the crude extract of $E$. hirta implies that the administration of plant extracts in the crude form might be safer than the fractionated or purified forms. This work justifies the use of these plants particularly in their crude form for treating diseases by herbal practitioners.

\section{Conclusions}

It might be concluded from the foregoing that extracts of both $E$. hirta and $R$. vomitoria possess antifilarial properties. Of the E. hirta extracts, that of ethyl acetate was found to be the most effective whilst the crude extract was the least toxic to monkey kidney cell lines. It is recommended that further efficacy determination of the 
extracts against both the mff and adult worms of the parasite and further toxicity studies be carried out.

\author{
Abbreviations \\ Mel B: Melarsoprol; DMSPN: Dimethanesulphonate; OCRC: Onchocerciasis \\ Chemotherapy Research Centre; DMSO: Dimethylsulfoxide (Merck, \\ Darmstadt), dried grade; MEM: Eagle's Minimum Essential Culture medium; E. \\ hirta: Euphorbia hirta; R. vomitoria: Rauvolfia vomitoria; OD: Optical density; \\ MTT: 3-(4, 5 dimethylthiazol-2-yl)-2 5-diphenyltetrazolium bromide; $O$. \\ volvulus: Onchocerca volvulus; Mff: Microfilariae.
}

\section{Competing interests}

The authors declare that they have no competing interests.

\section{Authors' contributions}

SKA: is the principal investigator, conceived and designed the work, carried out the extraction, data collection, analysis and interpretation.as part of a requirement for his PhD; PFA: supervised SKA for this work. AKN: also supervised SKA and contributed in the analysis and interpretation of data. AAS: assisted in the design of the work, arranged for the extraction, and freeze-drying of aqueous extracts. IVO: supplied the reagents, and supervised the extraction and freeze-drying of aqueous extracts in his laboratory. All authors contributed in the drafting and revision of the manuscript and gave their approval for the final version of the manuscript to be published.

\section{Acknowledgements}

It is our wish to thank the late Dr. G. K. Noamesi from whose garden the $R$. vomitoria plant materials were collected, Mr Patrick Ekpe at the Herbarium of the Botany Department of the University of Ghana for identifying the plant specimens. We are grateful to Dr. K. Awadzi, Director of the OCRC for partially financing the project, and the entire staff of the OCRC for the various roles played to bringing the work to completion.

\section{Author details}

'Department of Microbiology, University of Ghana Medical School, University of Ghana, Legon, Ghana. ${ }^{2}$ Centre for Scientific Research into Plant Medicine, Mampong-Akwapem, Ghana. ${ }^{3}$ Chemistry Department, University of Ghana, Legon, Accra, Ghana. ${ }^{4}$ Noguchi Memorial Institute for Medical Research, University of Ghana, Legon, Ghana.

Received: 13 October 2012 Accepted: 13 March 2013

Published: 18 March 2013

\section{References}

1. Nakajima A: The prevention of blindness - past present and future. Yen Ko Hsueh Pao 1992, 8(2):51-55.

2. Narita AS, Taylor HR: Blindness in the tropics. Med J Australia 1993, 159(6):416-420.

3. Thylefors B, Negrel AD, Pararajasegaram R, Dadzie KY: Global data on blindness. Bull WId HIth Org 1995, 73(1):115-121.

4. Whitcher JP, Srinivasan M, Upadhyay MP: Corneal blindness: a global perspective. Bull WId Hlth Org 2001, 79(3):214-221.

5. Prost A: The burden of blindness in adult males in the savanna villages of West Africa exposed to onchocerciasis. TransRoy Soc Trop Med Hyg 1986, 80(4):525-527.

6. Prost A, Vaugelade J: Excess mortality among blind persons in the West African Savannah zone. Bull WId Hlth Org 1981, 59:773-776.

7. WHO: Third Report of the Expert Committee on Onhocerciasis, Technical Report Series No. 752. Geneva, Switzerland: World Health Organisation; 1987.

8. WHO: New light shed on the importance and care of onchocercal skin disease, TDR news No. 55. 1998.

9. Amazigo UO: Detrimental effects of onchocerciasis on marriage age and breast feeding. Trop Geogr Med 1994, 46(5):322-325.

10. Ovuga EB, Ogwal-Okeny JW, Okello DO: Social anthropological aspects of onchocercal skin disease in Nebbi District, Uganda. East Afr Med J 1995, 72(10):649-653.
11. Brieger WR, Oshiname FO, Ososanya OO: Stigma associated with onchocercal skin disease among those affected near the Ofiki and Oyan Rivers in Western Nigeria. Soc SC Med 1998, 47(7):841-852.

12. Pion SD, Kamgno J, Demanga N, Boussinesq M: Excess mortality associated with blindness in the onchocerciasis focus of the Mbam valley, Cameroon. Ann Trop Med Parasitol 2002, 96(2):181-189.

13. Aziz MA: Ivermectin versus onchocerciasis. Parasitol Today 1986, 2(9):233-235.

14. Aziz MA, Diallo S, Diop IM, Lariviere M, Porta M: Efficacy and tolerance of ivermectin in human onchocerciasis. Lancet 1982, 2:171-173.

15. Aziz MA, Diallo S, Lariviere M, Diop IM, Porta M, Gaxotte P: Ivermectin in onchocerciasis. Lancet 1982, 2:1456-1457.

16. Awadzi K, Dadzie KY, Schulz-Key H, Haddock DRW, Gilles HM, Aziz MA: The chemotherapy of onchocerciasis $\mathrm{X}$ : An assessment of four single dose treatment regimes of MK-933 (ivermectin) in human onchocerciasis. Ann Trop Med Parasitol 1985, 79:63-78.

17. Awadzi K, Dadzie KY, Schulz-Key H, Gilles HM, Fulford AJ, Aziz MA: The chemotherapy of onchocerciasis XI: A double-blind comparative study of ivermectin, diethylcarbamazine and placebo in human onchocerciasis in northern Ghana. Ann Trop Med Parasitol 1986, 80(4):433-442.

18. Awadzi K, Attah SK, Addy ET, Opoku NO, Quartey BT: The effects of highdose ivermectin regimens on Onchocerca volvulus in onchocerciasis patients. Trans Roy Soc Trop Med Hyg 1999, 93:189-194.

19. Awadzi K, Boakye DA, Edwards G, Opoku NO, Attah SK, Osei-Atweneboana MY, Lazdins-Helds JK, Ardrey EA, Addy ET, Quartey BT, Ahmed K, Boatin BA Soumbey-Alley EW: An investigation of persistent microfilaridermias despite multiple treatments with ivermectin, in two onchocerciasisendemic foci in Ghana. Ann Trop Med Parasitol 2004a, 98(3):231-249.

20. Awadzi K, Attah SK, Addy ET, Opoku NO, Quartey BT, Lazdins-Helds JK, Ahmed K, Boatin BA, Boakye DA, Edwards G: Thirty-month follow-up of sub-optimal responders to multiple treatments with ivermectin, in two onchocerciasis-endemic foci in Ghana. Ann Trop Med Parasitol 2004, 98(4):359-370

21. Awadzi K, Edwards G, Opoku NO, Ardrey AE, Favager S, Addy ET, Attah SK, Yamuah LK, Quartey BT: The safety, tolerability and pharmacokinetics of levamisole alone, levamisole plus ivermectin, and levamisole plus albendazole, and their efficacy against Onchocerca volvulus. Ann Trop Med Parasit 2004, 98(6):595-614.

22. Eng JKL, Prichard RK: A comparison of genetic polymorphism in populations of Onchocerca volvulus from untreated- and ivermectintreated patients. Mol Biochem Parasitol 2005, 142:193-202.

23. Osei-Atwenebonna MY, Eng JKL, Boakye DA, Gyapong JO, Prichard RK: Prevalence and intensity of Onchocerca volvulus infection and efficacy of ivermectin in endemic communities in Ghana: a two-phase epidemiological study. Lancet 2007, 2369:2021-2029.

24. Osei-Atweneboana MY, Awadzi K, Attah SK, Boakye DA, Gyapong JO, Prichard RK: Phenotypic evidence of emerging ivermectin resistance in Onchocerca volvulus. PLoS Negl Trop Dis 2011, 5:e998.

25. Adedapo AA, Shabi OO, Adedokun OA: Anthelmintic efficacy of the aqueous crude extract of Euphorbia hirta Linn in Nigerian dogs. Vet Arhiv 2005, 75(1):39-47.

26. Adjanohoun E, Ahyi MRA, Ake Assi L, Dramane K, Elewude JA, Fadoju SO Gbile ZO, Goudote E, Johnson CLA, Keita A, Morakinyo O, Ojewole JAO, Olatunji O, Sofowora EA: Traditional Medicine and Pharmacopoeia: Contribution to Ethnobotanical and Floristic studies in western Nigeria. Lagos: Organization of African Unity's Scientific, Technical and Research Commission; 1991:308-354.

27. Ali M: Textbook of Pharmacognosy. 2nd edition. New Delhi: CBS. Publishers and Distributors; 1998:518.

28. TTC/CSIR: Ghana Herbal Pharmacopoeia. 1st edition. Accra, Ghana: Policy Research and Strategic Planning Institute (PORSPI) of the Council for Scientific and Industrial Research; 1992:205.

29. Sofowora A: Medicinal Plants and Traditional Medicine in Africa. 2nd edition. Ibadan, Owerri, Kaduna and Lagos: Spectrum Books Ltd; 1993:289.

30. Mshana NR, Abbiw DK, Addae-Mensah I, Adjanouhoun E, Ahyi MRA, Ekpere JA, Enow-Orock EG, Gbile ZO, Noamesi GK, Odei MA, Odunlami H, OtengYeboah AA, Sarpong K, Sofowora A, Tackie AN: Traditional Medicine and Pharmacopoeia: Contribution to the revision of ethnobotanical and floristic studies in Ghana. 1st edition. Accra: OAU/STRC document published by the Institute for Scientific and Technical Information; 2000:920. 
31. Moundipa PF, Melanie, Flore KG, Bilong Bilong CF, Bruchhaus I: In vitro amoebicidal activity of some medicinal plants of the Bamun Region (Cameroon). Afr J Trad Compl Altern Med 2005, 2(2):113-121.

32. Ogueke CC, Ogbulie JN, Okoli Cl, Anyanwu N: Antibacterial activity and toxicological potential of crude ethanolic extracts of Euphorbia hirta. J Amer Sc 2007, 3(3):11-16.

33. Kilian HD, Jahn $\mathrm{K}$, Kraus $\mathrm{L}$, Büttner DW: In vivo and in vitro effects of extracts from Cassia aubrevillei in onchocerciasis. Acta Leiden 1990, 59(1\&2):365-371.

34. Titanji VPK, Evehe MS, Ayafor JF, Kinbu SF: Novel Onchocerca volvulus filaricides from Caraca procera, Polyalthia suaveolens and Pachypodanthium staudtii. Acta Leiden 1990, 59(1\&2):377-382.

35. Ghosh M, Babu SP, Sukul NC, Mahato SB: Antifilarial effect of two triterpenoid saponins isolated from Acacia auriculiformis. Indian J Exp Biol 1993, 31(7):604-606.

36. Singh $R$, Khan NU, Singhall KC: In vitro antifilarial activity of Sencio nudicaulis Buch. Ham. Effect on Setaria cervi (Nematoda Filarioidea). Indian J Physiol Pharmacol 1996, 40:231-236.

37. Singh R, Singhal KC, Khan NU: Exploration of antifilarial potential and possible mechanism of action of the root extracts of Saxifraga stracheyion on cattle filarial parasite Setaria cervi. Phytother Res 2000, 14(1):63-66.

38. Singhal KC, Sharma S, Mehta BK: Antifilarial activity of Centratherum anthelminticum seed extracts on Setaria cervi. Indian J Exp Biol 1992, 30:546-548.

39. Mishra V, Khan NU, Singhal KC: Potential antifilarial activity of fruit extracts of Ficus recemosa (Linn.) against Setaria cervi in vitro. Indian Biol 2005a 43(4):346-350.

40. Mishra V, Parveen N, Singhal KC, Khan NU: Antifilarial activity of Azadirachta indica on cattle filarial parasite Setaria cervi. Fitoterapia 2005, 76(1):54-61.

41. Comley JCW, Titanji VPK, Ayafor JF, Singh VK: In vitro antifilarial activity of some medicinal plants. Acta Leiden 1990, 59(1\&2):361-363.

42. Hashemi SR, Zulkifli I, Hair Bejo M, Farida A, Somchit MN: Acute toxicity study and phytochemical screening of selected herbal aqueous extract in broiler chickens. Int J Pharmacol 2008, 4(5):352-360.

43. Otsyina HR: Toxicological evaluation of Cryptolepis sanquinolenta, Momordica charantia and Euphorbia hirta in rats. PhD thesis. Kwame Nkrumah University of Science and Technology, College of Health Sciences; 2010. Series 4931.

44. Brindha D, Saroja S, Jeyanthi GP: 2010 Protective potential of Euphorbia hirta against cytotoxicity induced in hepatocytes and a HepG2 cell line. J Basic Clin Physiol Pharmacol 2010, 21(4):401-413.

45. Raja Sidambaram R, Dinesh MG, Jayalakshmi ET: An in vitro study of cytotoxic activity of Euphorbia hirta on Hep2 cells of human epithelioma of larynx. Intern J Pharmacy Pharmaceutical Sc 2011, 3(Suppl 3). ISSN-0975-1491.

doi:10.1186/1472-6882-13-66

Cite this article as: Attah et al:: Extracts of Euphorbia hirta Linn. (Euphorbiaceae) and Rauvolfia vomitoria Afzel (Apocynaceae) demonstrate activities against Onchocerca volvulus Microfilariae in vitro. BMC Complementary and Alternative Medicine 2013 13:66.

\section{Submit your next manuscript to BioMed Central and take full advantage of:}

- Convenient online submission

- Thorough peer review

- No space constraints or color figure charges

- Immediate publication on acceptance

- Inclusion in PubMed, CAS, Scopus and Google Scholar

- Research which is freely available for redistribution

Submit your manuscript at www.biomedcentral.com/submit
( Biomed Central 